\title{
Physical Properties, Antioxidant Content and Anti-Oxidative Activities of Malaysian Stingless Kelulut (Trigona spp.) Honey
}

\author{
Boon Keng Chan ${ }^{1}$, Hasnah Haron ${ }^{1}$, Ruzita Abdul Talib ${ }^{1} \&$ Ponnusamy Subramaniam ${ }^{2}$ \\ ${ }^{1}$ Nutritional Sciences Programme, School of Healthcare Sciences, Faculty of Health Sciences, Universiti \\ Kebangsaan Malaysia, Kuala Lumpur, Malaysia \\ ${ }^{2}$ Programme of Health Psychology, School of Healthcare Sciences, Faculty of Health Sciences, Universiti \\ Kebangsaan Malaysia, Kuala Lumpur, Malaysia \\ Correspondence: Hasnah Haron, Nutritional Sciences Programme, School of Healthcare Sciences, Faculty of \\ Health Sciences, Universiti Kebangsaan Malaysia, Jalan Raja Muda Abdul Aziz, Kuala Lumpur 50300, Malaysia. \\ Tel: 60-392-897-457. Email: hasnaharon@ukm.edu.my
}

Received: October 3, $2017 \quad$ Accepted: December 6, $2017 \quad$ Online Published: December 31, 2017

doi:10.5539/jas.v9n13p32 URL: https://doi.org/10.5539/jas.v9n13p32

This study was funded by Universiti Kebangsaan Malaysia, under university research grant (GUP-056-2014).

\begin{abstract}
Honey produced by stingless bee of Trigona spp. is popularly known as Kelulut honey (KH) in Malaysia. Even though KH has been increasingly accepted by Malaysians, information relating to its physical and antioxidant properties is still limited. This study aimed to determine the physical properties, antioxidant content and anti-oxidative properties of KH collected from different regions in Peninsular Malaysia. Physical properties of $\mathrm{KH}$ including total soluble solids, $\mathrm{pH}$, moisture, ash content, and colour were determined. Antioxidant content namely total phenolics, flavonoids, carotenoids, ascorbic acid equivalent antioxidant content (AEAC) and quercetin equivalent antioxidant content (QEAC) were also quantified. Anti-oxidative potential of $\mathrm{KH}$ was assayed using DPPH radical scavenging and FRAP assays. KH has $\mathrm{pH}$ of 3.29-3.71, total soluble solids (66.23-73.70 ${ }^{\circ}$ Brix), $21.40-31.59 \%$ moisture and $0.22-0.41 \%$ ash content. Colour measurement showed KH from the northern region was lightest $(\mathrm{L}=39.32)$ while KH from east coast $(b=-5.06)$ and central $(a=5.65)$ regions were more pronounce in blue and red colours. $\mathrm{KH}$ from east coast region showed highest values for phenolics $(1169.36 \pm 51.11 \mathrm{mg} \mathrm{GAE} / \mathrm{kg}$ ), flavonoids $(79.13 \pm 0.49 \mathrm{mg} \mathrm{QE} / \mathrm{kg})$, carotenoids $(4.61 \pm 0.38 \mathrm{mg} / \mathrm{kg})$, AEAC $(146.20 \pm 5.56 \mathrm{mg} / \mathrm{kg})$ and QEAC $(177.08 \pm 5.54 \mathrm{mg} / \mathrm{kg})$. In line with the antioxidant content, honey from the east coast region also had strongest anti-oxidative activities indicated in its lowest $\mathrm{IC}_{50}$ value of DPPH radicals $(15.07 \pm 1.05 \mathrm{mg} / \mathrm{mL})$ and highest FRAP value $(7477.03 \pm 48.80 \mu \mathrm{MFe}(\mathrm{II}) / \mathrm{kg})$. The $\mathrm{KH}$ collected from different regions showed varied physical and antioxidant attributes which may due to variety source of floral origin.
\end{abstract}

Keywords: Trigona, antioxidant, anti-oxidative, physical properties

\section{Introduction}

In Malaysia, there are several types of honey produced in this tropical country such as Tualang honey, Pineapple honey, Gelam honey and Acacia honey. Recently, Kelulut honey (KH) is increasingly receiving substantial attention from Malaysians due to its distinct flavour and unique sour taste. Unlike other Malaysian honeys, KH is a multifloral honey from stingless bees and it obtained its name from the bees producing it that are locally known as Kelulut. Kelulut bees are from genus Trigona, the largest genus of stingless bees that are indigenous to Neotropics and Indo-Australian regions (Michener, 2000). The bees store their honey in small resin pots near the end of their nests while the honeybees Apis spp. store their honey in hexagonal-shaped combs (Kek et al., 2014). Trigona angustula has been used widely in Guatemala, Mexico and Venezuela for stomach disorders, cataract and pterygion, respiratory infections and wound healing (Vit et al., 2004). Trigona carbonaria that is well known in Australian has been proven to have anti-oxidative and antibacterial properties (Oddo et al., 2008; Boorn et al., 2009).

While market caters a wide range of choices, quality of honey is remained as important issues for consumers. Physical properties are considered as a pivotal domain to determine quality of a honey, affecting the shelf life 
and biological activities of honey. Confirming this assertion, international regulatory parties of honey has recommended limit for certain physical parameters. For instance, moisture content of a honey should be not more than 20\% (Codex Alimentarius, 2001; EU Council Directive, 2001). Research works has been conducted on Malaysian honey, concluding the moisture content of Malaysian honeys has complied with the limit prescribed (Moniruzzaman et al., 2013a, 2013b). Nevertheless, KH was left out in these studies. This study bridged the gaps of previous studies to provide information pertaining to physical properties of this honey.

Honey has been reported to have more than 200 compounds with sugar as its main components (Escuredo et al., 2013). Phenolic acids, flavonoids and carotenoids are bioactive compounds found in the honey with excellent antioxidant properties. However, these compounds are affected by floral origin, thus causing vast multifarious anti-oxidative properties of different honeys. The notion of natural foods rich in antioxidants are able to scavenge radicals and reduce oxidative stress in human body has been well discerned. Anti-oxidative capacity of honey is believed to be able to alleviate pathological conditions such as cancer, cardiovascular diseases and diabetes. This study aimed to reveal the unexplored antioxidant content and anti-oxidative potential of KH.

\section{Methods}

\subsection{Sample Collection}

KH samples were collected at east coast (Pahang), northern (Kedah) and central (Selangor) regions of Peninsular Malaysia. Two batches of samples were collected from each location and each batch of sample was analysed in three replicates in all analyses. The results were expressed as the average \pm standard deviation from six replicates of samples from the same location.

\subsection{Physical Analyses of Kelulut Honey}

\subsubsection{Moisture Content}

The moisture content in $\mathrm{KH}$ was analysed using table top reflectometer (Abbe, Spain) and the measurements were corrected for the standard temperature of $20{ }^{\circ} \mathrm{C}$ with a factor of $0.00023 /{ }^{\circ} \mathrm{C}$. Wedmore's table was used to determine the moisture content corresponding to the corrected refractive index (AOAC, 1990).

\section{$2.2 .2 \mathrm{pH}$}

KH sample with concentration of $10 \%$ (w/v) was analysed using $\mathrm{pH}$ meter (Mettler Toledo, Switzerland).

\subsubsection{Total Soluble Solid of Honey}

Total soluble solid in KH was tested using handheld refractometer (Atago, Japan). Two drops of concentrated honey was placed and spread on entire surface of the prism of the refractometer and the readings were measured as ${ }^{\circ}$ Brix.

\subsubsection{Ash Content}

$5.0 \mathrm{~g}$ of $\mathrm{KH}$ sample was measured inside crucible and ash was obtained by ignition at $550{ }^{\circ} \mathrm{C}$ in a furnace (Carbolite Gero, UK) for overnight (AOAC, 1990).

\subsubsection{Colour Intensity}

The colour intensity in KH was determined using method of Beretta et al. (2005) by absorbance difference of honey at $450 \mathrm{~nm}$ and $720 \mathrm{~nm}$ using spectrophotometer (Secomam, France). The honey samples were diluted to $50 \%(\mathrm{w} / \mathrm{v})$ solution with warm $\left(45-50^{\circ} \mathrm{C}\right)$ milli-Q water. The solution was filtered through a $0.45 \mu \mathrm{m}$ filter paper. The difference in absorbance was expressed as $\mathrm{mAU}$.

\subsubsection{Tristimulus Colour Analysis}

The colour measurement in KH was performed using handheld chroma meter (Minolta, Japan). Honey sample $(20 \mathrm{~g})$ was poured into glass cell and the reflectance spectrum was measured. The color parameters corresponding to the uniform CIELAB color space in which two color coordinates, $\mathrm{a}^{*}$ and $\mathrm{b}^{*}$, as well as lightness, $\mathrm{L}^{*}$, were determined.

\subsection{Antioxidant Content}

\subsubsection{Total Phenolics}

The Folin-Ciocalteu assay (Singleton et al., 1999) was used to quantify total phenolic content in KH. Approximately $0.5 \mathrm{~mL} 10 \%$ honey solution was mixed with $2.5 \mathrm{~mL} 0.2 \mathrm{~N}$ Folin-Ciocalteu reagent for 5 min. Subsequently, $2 \mathrm{~mL}$ of $7.5 \%$ of sodium carbonate solution was added. The mixture was allowed to incubate at room temperature for $2 \mathrm{~h}$. The absorbance of the mixture was then measured at $760 \mathrm{~nm}$ using spectrophotometer 
(Secomam, France) against methanol as blank. Gallic acid (50-200 mg/L) was used to produce standard curve $\left(\mathrm{R}^{2}=0.987\right)$. The total phenolic content was expressed in $\mathrm{mg}$ of gallic acid equivalents $(\mathrm{GAE}) / \mathrm{kg}$ honey.

\subsubsection{Total Flavonoids}

Total flavonoid content in KH samples was assayed using the protocol described by Zhishen et al. (1999). A 1 $\mathrm{mL} 20 \%$ honey was mixed with $4 \mathrm{~mL}$ distilled water and $0.3 \mathrm{~mL}$ sodium nitrite. Following $5 \mathrm{~min}, 0.3 \mathrm{~mL} 10 \%$ aluminium chloride was added and followed by the addition of $2 \mathrm{~mL} 1 \mathrm{M}$ sodium hydroxide at six min later. The volume was made up to $10 \mathrm{~mL}$ by distilled water. The mixture was shaken thoroughly and the absorbance was read using spectrophotometer (Secomam, France) at wavelength $510 \mathrm{~nm}$. A standard curve was plotted using quercetin solution of concentrations $25-100 \mu \mathrm{g} / \mathrm{mL}\left(\mathrm{R}^{2}=0.987\right)$. The results were expressed as $\mathrm{mg}$ quercetin equivalents $(\mathrm{QE}) / \mathrm{kg}$ honey.

\subsubsection{Ascorbic Acid and Quercetin Equivalent Antioxidant Content (AEAC \& QEAC)}

AEAC and QEAC in KH were performed according to the procedure described by Meda et al. (2005). A 0.75 $\mathrm{mL}$ honey in methanol $(0.04 \mathrm{~g} / \mathrm{mL})$ was mixed with $1.5 \mathrm{~mL} 0.02 \mathrm{mg} / \mathrm{mL}$ methanolic DPPH radical solution. The mixture was left for $15 \mathrm{~min}$ at room temperature before the determination of the absorbance using spectrophotometer (Secomam, France) at wavelength $517 \mathrm{~nm}$. The blank sample was made up from $0.75 \mathrm{~mL}$ honey solution with $1.5 \mathrm{~mL}$ methanol. The AEAC and QEAC were determined using standard curves from ascorbic acid $(2.5-10 \mu \mathrm{g} / \mathrm{ml})$ and quercetin $(2.5-10 \mu \mathrm{g} / \mathrm{ml})$, respectively. The results were expressed as $\mathrm{mg}$ AEAC or mg QEAC per kg honey.

\subsubsection{Carotenoid Content}

The measurement of carotenoid in KH was performed based on the protocol of Ferreira et al. (2009). A $100 \mathrm{mg}$ honey sample was shaken with mixture of acetone and hexane with the ratio of 4:6 for $1 \mathrm{~min}$. The mixture was filtered with filter paper and the absorbance of the filtrate was determined using spectrophotometer (Secomam, France) at wavelength 454,505 and $663 \mathrm{~nm}$. Content of $\beta$-carotene was obtained using the equation of $0.216 \mathrm{~A}_{663}$ $-0.304 \mathrm{~A}_{505}+0.452 \mathrm{~A}_{453}$ while lycopene content was calculated using the equation of $-0.0458 \mathrm{~A}_{663}+0.372 \mathrm{~A}_{505}-$ $0.0806 \mathrm{~A}_{453}$. The total carotenoid was the sum of $\beta$-carotene and lycopene, and all measurements were expressed in $\mathrm{mg} / 100 \mathrm{~mL}$.

\subsection{Anti-Oxidative Activities}

\subsubsection{DPPH Free Radical Scavenging Activity}

The scavenging activity of the DPPH radical in KH was conducted based on the procedure of Ferreira et al. (2009). Approximately $0.5 \mathrm{~mL} 0.2 \mathrm{~g} / \mathrm{mL}$ honey extract was mixed with $2.7 \mathrm{~mL}$ methanolic $0.024 \mathrm{mg} / \mathrm{mL} \mathrm{DPPH}$ radical solution. The mixture was vigorously shaken and incubated for $15 \mathrm{~min}$ prior to the measurement of absorbance at $517 \mathrm{~nm}$. The radical-scavenging activity (RSA) was calculated using the following equation:

$$
\% \mathrm{RSA}=\left[\left(A_{D P P H}-A_{S}\right) / A_{D P P H}\right] \times 100
$$

where, $A_{S}$ is the absorbance of the sample with radicals and $A_{D P P H}$ is the absorbance of the DPPH radical solution. $\mathrm{IC}_{50}$ was determined as the concentration scavenging $50 \%$ of DPPH radicals.

\subsubsection{Ferric Reducing Antioxidant Power (FRAP)}

This assay was performed using protocol of Benzie and Strain (1999). A $200 \mu \mathrm{L} 0.1 \mathrm{~g} / \mathrm{mL}$ honey was mixed with $1.5 \mathrm{~mL}$ of FRAP reagent prepared from acetate buffer $(300 \mathrm{mM} / \mathrm{L}), 2,4,6$-tris(2-pyridyl)-s-triazine (TPTZ) solution $(10 \mathrm{mM}$ in $40 \mathrm{mM} / \mathrm{L} \mathrm{HCl})$, ferric chloride $\left(\mathrm{FeCl}_{3} \cdot 6 \mathrm{H}_{2} \mathrm{O}\right)(20 \mathrm{mM})$ in the ratio of 10:1:1. The mixture was pre-warmed at $37{ }^{\circ} \mathrm{C}$ for $4 \mathrm{~min}$ before the measurement of absorbance at wavelength $593 \mathrm{~nm}$ using spectrophotometer (Secomam, France). Ferrous sulfate $\left(\mathrm{FeSO}_{4} \cdot 7 \mathrm{H}_{2} \mathrm{O}\right)$ of concentrations $250-1000 \mu \mathrm{M} / \mathrm{L}$ was used to construct the standard curve $\left(\mathrm{R}^{2}=0.991\right)$. The FRAP values were expressed as $\mu \mathrm{M} \mathrm{Fe}[\mathrm{II}]$ per kg honey.

\subsection{Data Analysis}

IBM SPSS version 23 was employed for the statistical analyses. ANOVA with Tukey's Honest Significant Difference (HSD) test was used for comparisons of physical and antioxidant attributes of KH from three different zones. The significant level was set as $\alpha=0.05$.

\section{Results and discussion}

\subsection{Total Soluble Solids, $p H$, Moisture and Ash Content of KH}

The total soluble solids (66.23-73.70 ${ }^{\circ} \mathrm{Brix}$ ) in $\mathrm{KH}$ of this study (Table 1) were lower than the values found in previous study (76.2-80.4 ${ }^{\circ}$ Brix) (Saxena et al., 2010). Total soluble solids can be used as an estimation of sugar 
content in which higher total soluble solid value corresponds to higher sweetness (Magwaza \& Opara, 2015). Sugars are the main components that are soluble in honey. However, it is not an accurate method to quantify the sugar content as other components in honey such as organic and amino acids may contribute to this reading too.

Table 1. Physical characteristics of KH

\begin{tabular}{llll}
\hline Parameters & East coast region honey & Northern region honey & Central region honey \\
\hline pH & $3.71 \pm 0.04^{\mathrm{a}}$ & $3.71 \pm 0.04^{\mathrm{a}}$ & $3.29 \pm 0.20^{\mathrm{b}}$ \\
Moisture content (\%) & $31.59 \pm 3.12^{\mathrm{a}}$ & $25.10 \pm 1.37^{\mathrm{b}}$ & $21.40 \pm 1.23^{\mathrm{c}}$ \\
Ash Content (\%) & $0.41 \pm 0.08^{\mathrm{a}}$ & $0.23 \pm 0.03^{\mathrm{b}}$ & $0.22 \pm 0.10^{\mathrm{b}}$ \\
Total Soluble Solids ('Brix) & $66.23 \pm 0.13^{\mathrm{a}}$ & $73.70 \pm 0.12^{\mathrm{b}}$ & $70.10 \pm 0.70^{\mathrm{c}}$ \\
Color intensity (mAU) & $2103.17 \pm 3.19^{\mathrm{a}}$ & $1200.50 \pm 3.21^{\mathrm{b}}$ & $1029.00 \pm 40.16^{\mathrm{c}}$ \\
Tristimulus color & & & \\
L & $35.90^{\mathrm{a}}$ & $39.32^{\mathrm{b}}$ & $34.57^{\mathrm{c}}$ \\
a & $4.94^{\mathrm{a}}$ & $3.98^{\mathrm{b}}$ & $5.65^{\mathrm{c}}$ \\
$\mathbf{b}$ & $-5.06^{\mathrm{a}}$ & $-4.13^{\mathrm{a}}$ & $-5.04^{\mathrm{a}}$ \\
\hline
\end{tabular}

Note. Different letters within the same row indicate the significant difference $(\mathrm{p}<0.05)$ among samples.

The $\mathrm{pH}$ values of the tested honey samples were in the range of 3.29-3.71. This range was in fair agreement with the values reported in previous studies (3.3-4.7) (de Rodríguez et al., 2004; Silva et al., 2009). Oddo et al. (2008) reported Australian Trigona carbonaria honey had a $\mathrm{pH}$ of $4.0 \pm 0.1$, while Trigona laeviceps honey from Thailand exhibited a pH of 3.37 (Chanchao, 2009), indicating Malaysian stingless bee honey used in this study had similar $\mathrm{pH}$ as stingless bee honeys from other parts of the world. The $\mathrm{pH}$ value of honey is influenced by several factors including extraction and storage conditions, while $\mathrm{pH}$ itself acts as an attribute to affect texture, stability and shelf-life of honey. This attribute serves as a reliable indicator of microbial stability as most of the bacteria grow in neutral and slightly alkaline medium (Silva et al., 2009). Besides, the acidity gives extra flavor to honey.

Moisture content is an important parameter in determining quality of a honey as high moisture content may reduce the shelf life and microbial stability of a honey. $\mathrm{KH}$ in this study were reported to have moisture content of 21.4-31.59\%. Trigona nigra honey contained 36.2\% of moisture (Bijlsma et al., 2006) and Trigona carbonaria honey possessed a moisture content of $26.2 \%$ (Oddo et al., 2008). The seasonal weather conditions and regional humidity of collection areas are the main factors that influence the moisture content which might be able to explain the great difference of moisture content among honey from different regions of this study. KH had higher moisture content than honey of Apis spp. in Malaysia (14.86-19.06\%) (Moniruzzaman et al., 2013a, $2013 b)$. Drying process is recommended for this honey following harvesting from the beehive in order to extend the shelf-life of the honey. However, the temperature of drying need to be set low since the phenolics can be destroyed at high temperatures.

The ash content in $\mathrm{KH}$ was in the range of $0.22-0.41 \%$, which was within the values reported by previous studies (0.03-1.23) (Malika et al., 2005; Al et al., 2009; Silva et al., 2009). Floral honey should have low ash content. The high dispersion in ash content of honey from different regions may be due to the non-uniformness of techniques used in harvesting and beekeeping process (Finola et al., 2007). Nonetheless, ash content of honey can be varied due to the foraging activities of bees on the floral (de Rodriguez et al., 2004).

\subsection{Colour Measurements of $\mathrm{KH}$}

$\mathrm{ABS}_{450}$ is an indication for the presence of colour pigments such as carotenoids and some flavonoids in honey. However, it could be also contributed by contaminating pigments during the handling, processing and storage of honeys as well by-products of biochemical reactions during honey maturation which did not possess any anti-oxidative properties (Baretta et al., 2005).

$\mathrm{KH}$ used in this study had $\mathrm{ABS}_{450}$ values at the range of 1029.00-2103.17 mAU. This range was greater than 169.89-740.59 mAU reported by Khalil et al. (2011) and 204-805 mAU by Moniruzzaman et al. (2013b) for various types of Malaysian honey produced by Apis spp. honeybees. The higher values of $\mathrm{ABS}_{450}$ in $\mathrm{KH}$ indicated this honey had higher content color pigments as compared to other Malaysian honeys, giving an added-value to this honey originated from stingless bees. Comparing with honeys from other countries, $\mathrm{ABS}_{450}$ 
of KH was still higher than 70-495 mAU for Slovenian honeys 60 (Bertoncelj et al., 2007), but lower than several types of Italian honeys (25-3413 mAU) (Baretta et al., 2005).

Visual colour of KH were examined in three aspects namely L (lightness), a (redness or greenness) and $b$ for (yellowness or blueness). KH from northern region $(\mathrm{L}=39.32$ ) showed the maximum lightness while the central region honey showed the minimum lightness $(\mathrm{L}=34.57)$. The values obtained in this study were lower than those reported for Indian honey (40.96-53.53) (Ahmed et al., 2007) and Slovenian honey (42.12-64.60) (Bertoncelj et al., 2007). The positive a value indicated the presence of red components in the KH whereas the negative $\mathrm{b}$ values meant the $\mathrm{KH}$ contained blue components.

\subsection{Total Phenolics and Flavonoids in KH}

Total phenolics found in the KH in this study were ranging from 525.16 to $1169.36 \mathrm{mg}$ GAE $/ \mathrm{kg}$ (Table 2). KH from the three different regions has a vast difference in their phenolic content. Despite being produced by the same bees (Trigona spp.), but the different botanical origin in different regions of Peninsular Malaysia has contributed to this difference. KH is a multifloral honey with no predominant pollen in this honey. The honey was made up from blending of different pollens that were significantly affected by botanical origin, this may clearly explain for the significant difference $(\mathrm{p}<0.05)$ for the same type of honey collected from three different regions. Pollen collected from floral origin is the sole contributing source for phenolic content in honey. This was due to the fact that the group of bioactive compounds can only be obtained from plants since bees are unable to secrete any of phenolics from its hypopharyngeal gland.

The phenolic content reported for honey from other geographical origins were 32.59-114.75 mg GAE/100 $\mathrm{g}$ for Burkina Fasan honey (Meda et al., 2005), 56.32-246.31 catechin equivalent (CE)/100 g for Yemeni honey (Al-Mamary et al., 2002), 89.98-215.17 mg GAE/kg for Czech honey (Lachman et al., 2010) and 0.24-111.33 $\mathrm{mg} \mathrm{GAE} / 100 \mathrm{~g}$ for Turkish honey (Silici et al., 2010). The marked difference in reported values has again highlighted the importance of geographical origin that influenced phenolic content of the honey. Comparing with the results from this study, the values of the total phenolics of KH from this study was within the range of previously reported values for honey from various regions mentioned. Meanwhile, the total flavonoids of KH (44.60-79.13 mg QE/ $\mathrm{kg}$ ) were within the range of values $(0.91-28.25 \mathrm{mg} \mathrm{QE} / 100 \mathrm{~g})$ reported for Romanian honey from different floral origin (Al et al., 2009). Flavonoids are one of the main classes polyphenols present in pollen collected by honeybees (Kroyer \& Hegedus, 2001). This group of bioactive compounds serves as an excellent antioxidant that helps in scavenging free radicals. Flavonoids stabilize and neutralize reactive oxygen species to form a less reactive radical (Nijveldt et al., 2001).

Table 2. Antioxidant content of KH

\begin{tabular}{llll}
\hline Parameters & East coast region honey & Northern region honey & Central region honey \\
\hline TPC $(\mathrm{mg} \mathrm{GAE} / \mathrm{kg})$ & $1169.36 \pm 51.11^{\mathrm{a}}$ & $720.81 \pm 47.50^{\mathrm{b}}$ & $525.16 \pm 26.38^{\mathrm{c}}$ \\
TFC $(\mathrm{mg} \mathrm{QE} / \mathrm{kg})$ & $79.13 \pm 0.49^{\mathrm{a}}$ & $50.14 \pm 8.23^{\mathrm{b}}$ & $44.60 \pm 4.60^{\mathrm{b}}$ \\
AEAC $(\mathrm{mg} / \mathrm{kg})$ & $146.20 \pm 5.56^{\mathrm{a}}$ & $8.26 \pm 3.44^{\mathrm{b}}$ & $96.64 \pm 1.52^{\mathrm{c}}$ \\
QEAC $(\mathrm{mg} / \mathrm{kg})$ & $177.08 \pm 5.54^{\mathrm{a}}$ & $39.75 \pm 3.43^{\mathrm{b}}$ & $127.74 \pm 1.51^{\mathrm{c}}$ \\
Lycopene $(\mathrm{mg} / \mathrm{kg})$ & $1.52 \pm 0.16^{\mathrm{a}}$ & $0.65 \pm 0.08^{\mathrm{b}}$ & $0.76 \pm 0.07^{\mathrm{c}}$ \\
$\beta$-carotene $(\mathrm{mg} / \mathrm{kg})$ & $3.09 \pm 0.23^{\mathrm{a}}$ & $1.58 \pm 0.12^{\mathrm{b}}$ & $1.55 \pm 0.06^{\mathrm{b}}$ \\
\hline
\end{tabular}

Note. Different letters within the same row indicate the significant difference $(\mathrm{p}<0.05)$ among samples.

\subsection{AEAC, QEAC and Carotenoid Content of KH}

The AEAC of KH (8.26-146.20 mg/kg) was lower than those of India (15.1-29.5 mg/100 g) (Saxena et al., 2010), Bangladesh (18.4-34.1 mg/100 g) (Islam et al., 2012) and Algeria (23.68-31.59 mg/100 g) (Khalil et al., 2012) honey. KH from the east coast $(177.08 \pm 5.54 \mathrm{mg} / \mathrm{kg})$ and central $(127.74 \pm 1.51 \mathrm{mg} / \mathrm{kg})$ regions contained QEAC within the range of previous study (4.27-33.34 mg/100 g) (Meda et al., 2005). Despite all the honey being produced by Trigona spp. bees, both AEAC and QEAC of three honey were significantly different $(\mathrm{p}<0.05)$, indicating the important roles of floral source in antioxidant content of honey.

The lycopene content of KH was $0.65-1.52 \mathrm{mg} / \mathrm{kg}$ while the $\beta$-carotene content was $1.55-3.09 \mathrm{mg} / \mathrm{kg}$. These values were lower than those reported by Ferreira et al. (2009) ( $\beta$-carotenoids of $8.64-9.49 \mathrm{mg} / \mathrm{kg}$; lycopene of $6.12-6.55 \mathrm{mg} / \mathrm{kg}$ ) but the total carotenoids in this study $(2.23-4.61 \mathrm{mg} / \mathrm{kg})$ was in line with carotenoids of Cuban honey (1.17-5.57 mg/kg) (Alvarez-Suarez et al., 2010). 


\subsection{Anti-Oxidative Activities of $\mathrm{KH}$}

The DPPH assay determines the free radical scavenging activity of honey using stable organic radical 1,1-diphenyl-2-picrylhydrazyl. The $\mathrm{IC}_{50}$, the amount of honey needed to reduce the initial DPPH concentration by $50 \%$, was used as an indicator to compare anti-oxidative capacity of honey in which honey with stronger anti-oxidative potency exhibit lower values (Molyneux, 2004). KH from the east coast region exerted the strongest scavenging activity against DPPH radicals with scavenging percentage of $44.12-79.99 \%$ in concentration $\left(10-60 \mathrm{mg} / \mathrm{mL}\right.$ ) (Figure 1) and the lowest $\mathrm{IC}_{50}$ value of $15.07 \pm 1.05 \mathrm{mg} / \mathrm{mL}$ as compared to $23.98 \pm 2.20 \mathrm{mg} / \mathrm{mL}$ and $28.86 \pm 1.70 \mathrm{mg} / \mathrm{mL}$ for honey from the central and northern regions, respectively. Explicitly, the $\mathrm{IC}_{50}$ for all three honey were significantly different $(\mathrm{p}<0.01)$ and fell within the range of previous studies (1.37-53.80 mg/mL) (Meda et al., 2005; Bertoncelj et al., 2007).

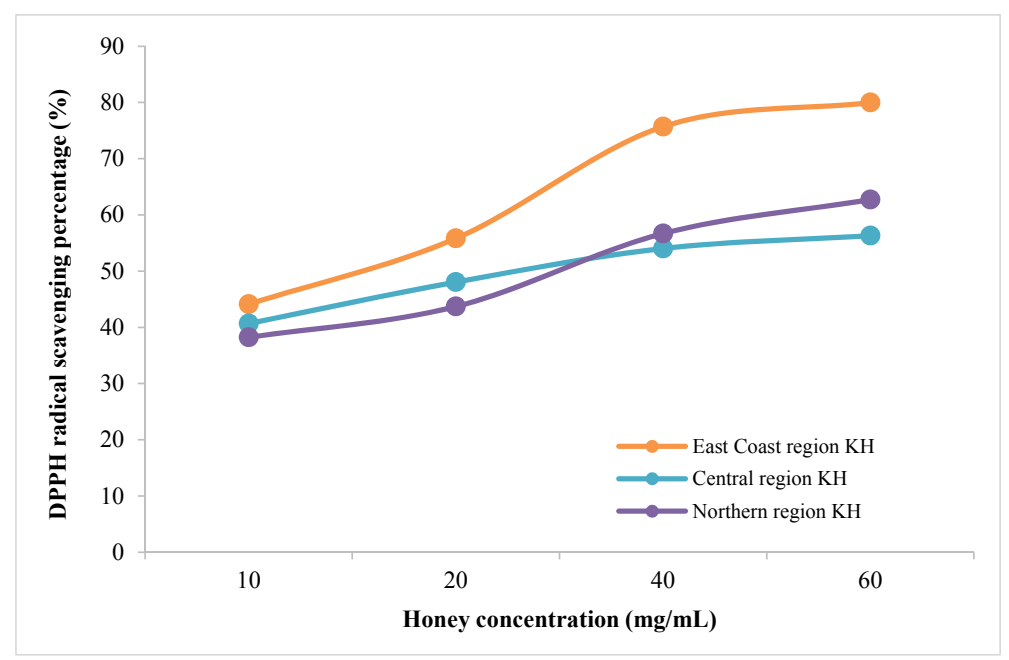

Figure 1. Scavenging activity of DPPH radicals

The FRAP assay estimates the antioxidants and reductants present in honey sample that are able to reduce the $\mathrm{Fe}^{3+} / \mathrm{Fe}^{2+}$ couple (Beretta et al., 2005). The FRAP values of the tested honey samples were 3630.18-7477.03 $\mu \mathrm{M}$ $\mathrm{Fe}(\mathrm{II}) / \mathrm{kg}$ (Figure 2), and the reducing capacity of KH from east coast was highest followed by KH from northern and central regions. Apparently, the results from this study were higher than those reported for Tualang, Gelam, Indian forest and pineapple honey (47.92-121.89 $\mu \mathrm{M} \mathrm{Fe(II)/100} \mathrm{g)} \mathrm{(Kishore} \mathrm{et} \mathrm{al.,} \mathrm{2011).} \mathrm{The} \mathrm{coincidence} \mathrm{of}$ honey from the east coast region having the highest phenolics, flavonoids and FRAP value emphasized contributions of these bioactive compounds in anti-oxidative activity.

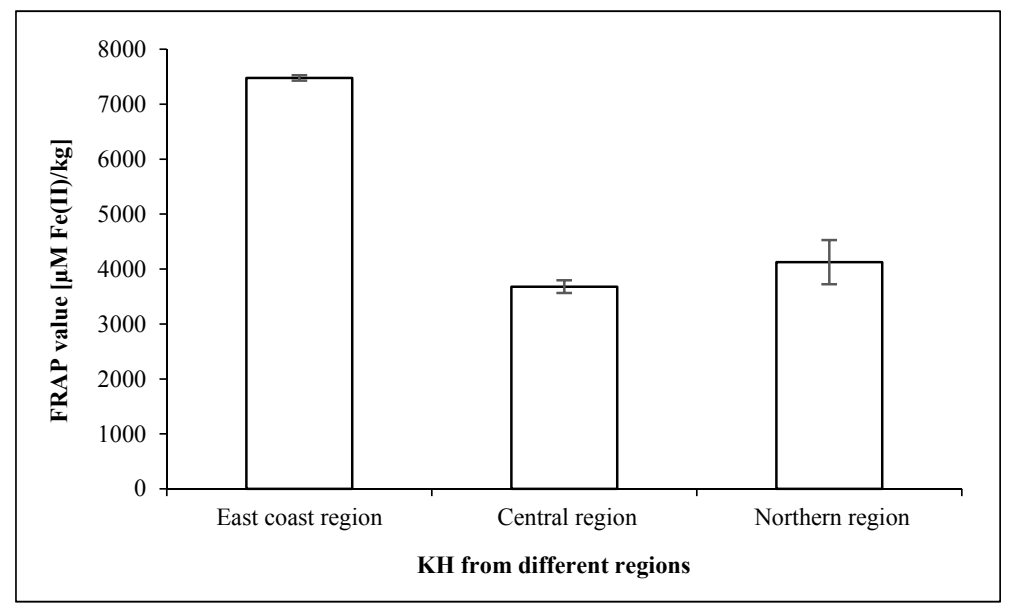

Figure 2. FRAP values of KH 


\section{Conclusions}

The physical properties, antioxidant content and anti-oxidative activities of KH were differed greatly with the geographical origin. Confirming this assertion, the authority governing the production of this honey should generate a grading system as part of the effort to promote this honey. Grading system can be based on the antioxidant content of this honey and consumers can be benefited from this for choosing honey with more antioxidants for their health purpose. Meanwhile, the higher moisture content of the honey might need to be reduced using low temperature drying. This will lower down the moisture content while increase its stability from microorganism and preserve the antioxidant content of $\mathrm{KH}$.

\section{Acknowledgements}

The authors would like to acknowledge Universiti Kebangsaan Malaysia for the financial support (University Research Grant, GUP-056-2014) of this study.

\section{References}

Ahmed, J., Prabhu, S. T., Raghavan, G. S. V., \& Ngadi, M. (2007). Physico-chemical, rheological, calorimetric and dielectric behavior of selected Indian honey. Journal of Food Engineering, 79(4), 1207-1213. https://doi.org/10.1016/j.jfoodeng.2006.04.048

Al, M. L., Daniel, D., Moise, A., Bobis, O., Laslo, L., \& Bogdanov, S. (2009). Physico-chemical and bioactive properties of different floral origin honeys from Romania. Food Chemistry, 112(4), 863-867. https://doi.org/10.1016/j.foodchem.2008.06.055

Al-Mamary, M., Al-Meeri, A., \& Al-Habori, M. (2002). Antioxidant activities and total phenolics of different types of honey. Nutrition Research, 22(9), 1041-1047. https://doi.org/10.1016/S0271-5317(02)00406-2

Alvarez-Suarez, J. M., Tulipani, S., Díaz, D., Estevez, Y., Romandini, S., Giampieri, F., ... Battino, M. (2010). Antioxidant and antimicrobial capacity of several monofloral Cuban honeys and their correlation with color, polyphenol content and other chemical compounds. Food and Chemical Toxicology, 48(8), 2490-2499. https://doi.org/10.1016/j.fct.2010.06.021

AOAC. (1990). Official methods of analysis (p. 15). Arlington, VA, USA: Association of official Analytical Chemists.

Benzie, I. F., \& Strain, J. J. (1999). Ferric reducing/antioxidant power assay: Direct measure of total antioxidant activity of biological fluids and modified version for simultaneous measurement of total antioxidant power and ascorbic acid concentration. Methods in Enzymology, 299, 15-27. https://doi.org/10.1016/S0076-6879 (99)99005-5

Beretta, G., Granata, P., Ferrero, M., Orioli, M., \& Facino, R. M. (2005). Standardization of antioxidant properties of honey by a combination of spectrophotometric/fluorimetric assays and chemometrics. Analytica Chimica Acta, 533(2), 185-191. https://doi.org/10.1016/j.aca.2004.11.010

Bertoncelj, J., Doberšek, U., Jamnik, M., \& Golob, T. (2007). Evaluation of the phenolic content, antioxidant activity and colour of Slovenian honey. Food Chemistry, 105(2), 822-828. https://doi.org/10.1016/ j.foodchem.2007.01.060

Bijlsma, L., de Bruijn, L. L., Martens, E. P., \& Sommeijer, M. J. (2006). Water content of stingless bee honeys (Apidae, Meliponini): Interspecific variation and comparison with honey of Apis mellifera. Apidologie, 37(4), 480-486. https://doi.org/10.1051/apido:2006034

Boorn, K. L., Khor, Y. Y., Sweetman, E., Tan, F., Heard, T. A., \& Hammer, K. A. (2010). Antimicrobial activity of honey from the stingless bee Trigona carbonaria determined by agar diffusion, agar dilution, broth microdilution and time-kill methodology. Journal of Applied Microbiology, 108(5), 1534-1543. https://doi.org/10.1111/j.1365-2672.2009.04552.x

Chanchao, C. (2009). Antimicrobial activity by Trigona laeviceps (stingless bee) honey from Thailand. Pakistan Journal of Medical Sciences, 25(3), 364-9.

Codex Alimentarius. (2001). Revised codex standard for honey. Codex Standard, 12, 1982.

de Rodríguez, G. O., de Ferrer, B. S., Ferrer, A., \& Rodríguez, B. (2004). Characterization of honey produced in Venezuela. Food Chemistry, 84(4), 499-502. https://doi.org/10.1016/S0308-8146(02)00517-4 
Escuredo, O., Dobre, I., Fernández-González, M., \& Seijo, M. C. (2014). Contribution of botanical origin and sugar composition of honeys on the crystallization phenomenon. Food Chemistry, 149, 84-90. https://doi.org/10.1016/j.foodchem.2013.10.097

EU Council Directive. (2001). 110/EC of 20 December 2001 relating to honey. Official Journal of the European Communities, 10(12.1.2002), 47-52.

Finola, M. S., Lasagno, M. C., \& Marioli, J. M. (2007). Microbiological and chemical characterization of honeys from central Argentina. Food Chemistry, 100(4), 1649-1653. https://doi.org/10.1016/j.foodchem.2005. 12.046

Islam, A., Khalil, I., Islam, N., Moniruzzaman, M., Mottalib, A., Sulaiman, S. A., \& Gan, S. H. (2012). Physicochemical and antioxidant properties of Bangladeshi honeys stored for more than one year. $B M C$ Complementary and Alternative Medicine, 12(1), 1. https://doi.org/10.1186/1472-6882-12-177

Kek, S. P., Chin, N. L., Yusof, Y. A., Tan, S. W., \& Chua, L. S. (2014). Total phenolic contents and colour intensity of Malaysian honeys from the Apis spp. and Trigona spp. bees. Agriculture and Agricultural Science Procedia, 2, 150-155. https://doi.org/10.1016/j.aaspro.2014.11.022

Khalil, M. I., Mahaneem, M., Jamalullail, S. M. S., Alam, N., \& Sulaiman, S. A. (2011). Evaluation of radical scavenging activity and colour intensity of nine Malaysian honeys of different origin. Journal of ApiProduct and ApiMedical Science, 3(1), 04-11. https://doi.org/10.3896/IBRA.4.03.1.02

Khalil, M. I., Moniruzzaman, M., Boukraâ, L., Benhanifia, M., Islam, M. A., Islam, M. N., ... Gan, S. H. (2012). Physicochemical and antioxidant properties of Algerian honey. Molecules, 17(9), 11199-11215. https://doi.org/10.3390/molecules 170911199

Kishore, R. K., Halim, A. S., Syazana, M. N., \& Sirajudeen, K. N. S. (2011). Tualang honey has higher phenolic content and greater radical scavenging activity compared with other honey sources. Nutrition Research, 31(4), 322-325. https://doi.org/10.1016/j.nutres.2011.03.001

Kroyer, G., \& Hegedus, N. (2001). Evaluation of bioactive properties of pollen extracts as functional dietary food supplement. Innovative Food Science \& Emerging Technologies, 2(3), 171-174. https://doi.org/ 10.1016/S1466-8564(01)00039-X

Lachman, J., Orsák, M., Hejtmánková, A., \& Kováŕová, E. (2010). Evaluation of antioxidant activity and total phenolics of selected Czech honeys. LWT-Food Science and Technology, 43(1), 52-58. https://doi.org/ 10.1016/j.lwt.2009.06.008

Magwaza, L. S., \& Opara, U. L. (2015). Analytical methods for determination of sugars and sweetness of horticultural products-A review. Scientia Horticulturae, 184, 179-192. https://doi.org/10.1016/j.scienta. 2015.01 .001

Malika, N., Mohamed, F., \& Chakib, E. A. (2005). Microbiological and physicochemical properties of Moroccan honey. International Journal of Agriculture and Biology, 7(5), 773-776.

Meda, A., Lamien, C. E., Romito, M., Millogo, J., \& Nacoulma, O. G. (2005). Determination of the total phenolic, flavonoid and proline contents in Burkina Fasan honey, as well as their radical scavenging activity. Food Chemistry, 91(3), 571-577. https://doi.org/10.1016/j.foodchem.2004.10.006

Michener, C. D. (2000). The Bees of the World. Johns Hopkins University Press, Baltimore.

Molyneux, P. (2004). The use of the stable free radical diphenylpicrylhydrazyl (DPPH) for estimating antioxidant activity. Songklanakarin Journal of Science and Technology, 26(2), 211-219.

Moniruzzaman, M., Khalil, M. I., Sulaiman, S. A., \& Gan, S. H. (2013a). Physicochemical and antioxidant properties of Malaysian honeys produced by Apis cerana, Apis dorsata and Apis mellifera. BMC Complementary and Alternative Medicine, 13(1), 43. https://doi.org/10.1186/1472-6882-13-43

Moniruzzaman, M., Sulaiman, S. A., Khalil, M. I., \& Gan, S. H. (2013b). Evaluation of physicochemical and antioxidant properties of sourwood and other Malaysian honeys: A comparison with manuka honey. Chemistry Central Journal, 7(1), 138. https://doi.org/10.1186/1752-153X-7-138

Nijveldt, R. J., Van Nood, E. L. S., Van Hoorn, D. E., Boelens, P. G., Van Norren, K., \& Van Leeuwen, P. A. (2001). Flavonoids: A review of probable mechanisms of action and potential applications. The American Journal of Clinical Nutrition, 74(4), 418-425. 
Oddo, L. P., Heard, T. A., Rodríguez-Malaver, A., Pérez, R. A., Fernández-Muiño, M., Sancho, M. T., ... Vit, P. (2008). Composition and antioxidant activity of Trigona carbonaria honey from Australia. Journal of Medicinal Food, 11(4), 789-794. https://doi.org/10.1089/jmf.2007.0724

Saxena, S., Gautam, S., \& Sharma, A. (2010). Physical, biochemical and antioxidant properties of some Indian honeys. Food Chemistry, 118(2), 391-397. https://doi.org/10.1016/j.foodchem.2009.05.001

Silici, S., Sagdic, O., \& Ekici, L. (2010). Total phenolic content, antiradical, antioxidant and antimicrobial activities of Rhododendron honeys. Food Chemistry, 121(1), 238-243. https://doi.org/10.1016/j.foodchem. 2009.11.078

Silva, L. R., Videira, R., Monteiro, A. P., Valentão, P., \& Andrade, P. B. (2009). Honey from Luso region (Portugal): Physicochemical characteristics and mineral contents. Microchemical Journal, 93(1), 73-77. https://doi.org/10.1016/j.microc.2009.05.005

Singleton, V. L., Orthofer, R., \& Lamuela-Raventos, R. M. (1999). Analysis of total phenols and other oxidation substrates and antioxidants by means of Folin-Ciocalteu reagent. Methods in Enzymology, 299, 152-178. https://doi.org/10.1016/S0076-6879(99)99017-1

Vit, P., Medina, M., \& Eunice Enríquez, M. (2004). Quality standards for medicinal uses of Meliponinae honey in Guatemala, Mexico and Venezuela. Bee World, 85(1), 2-5. https://doi.org/10.1080/0005772X.2004. 11099603

Zhishen, J., Mengcheng, T., \& Jianming, W. (1999). The determination of flavonoid contents in mulberry and their scavenging effects on superoxide radicals. Food Chemistry, 64(4), 555-559. https://doi.org/10.1016/ S0308-8146(98)00102-2

\section{Copyrights}

Copyright for this article is retained by the author(s), with first publication rights granted to the journal.

This is an open-access article distributed under the terms and conditions of the Creative Commons Attribution license (http://creativecommons.org/licenses/by/4.0/). 